\title{
Sustainable Supply Chain Management in the Route for a Circular Economy: An Integrative Literature Review
}

\author{
Jorge Alfredo Cerqueira-Streit ${ }^{1, *(\mathbb{D})}$, Gustavo Yuho Endo ${ }^{2}\left(\mathbb{D}\right.$, Patricia Guarnieri $^{1}\left(\mathbb{C}\right.$ and Luciano Batista $^{3}(\mathbb{D})$ \\ 1 Postgraduate Program in Management, Business Department, University of Brasília, \\ Brasília 70910-900, Brazil; patriciaguarnieris@gmail.com \\ 2 Postgraduate Program in Production Engineering, Federal Technological University of Paraná, \\ Ponta Grossa 84017-220, Brazil; yuho.endo@gmail.com \\ 3 Aston Business School, Aston University, Birmingham B4 7ET, UK; L.Batista@aston.ac.uk \\ * Correspondence: jorgealfredocs@gmail.com
}

Citation: Cerqueira-Streit, J.A.; Endo, G.Y.; Guarnieri, P.; Batista, L.

Sustainable Supply Chain

Management in the Route for a Circular Economy: An Integrative

Literature Review. Logistics 2021, 5, 81. https://doi.org/10.3390/

logistics5040081

Academic Editor: Robert Handfield

Received: 29 September 2021

Accepted: 11 November 2021

Published: 17 November 2021

Publisher's Note: MDPI stays neutral with regard to jurisdictional claims in published maps and institutional affiliations.

Copyright: ( $\odot 2021$ by the authors. Licensee MDPI, Basel, Switzerland. This article is an open access article distributed under the terms and conditions of the Creative Commons Attribution (CC BY) license (https:// creativecommons.org/licenses/by/ $4.0 /)$.

\begin{abstract}
Background: Sustainable supply chain management (SSCM) considers social, environmental, and economic dimensions of sustainability. In the context of the pandemic, organizations must face consequences striking the wider dimensions of sustainability. Thus, after the COVID-19 pandemic, how will the value chains collaborate for the transition from a traditional (linear) to a Circular Economy? Methods: From this question, in this paper, we analyze the international papers that connect sustainable supply chain management (SSCM) with circular economy (CE). We conducted an Integrative Literature Review based on the Web of Science and Scopus databases from 2010 to 2020, using the Methodi Ordinatio protocol to classify the papers. Results: The 37 best-ranked papers were analyzed thoroughly. The results show the prominent authors, institutions, the network relationship between authors, the evolution of publications, and the leading journals. The content of these articles was categorized and discussed about the changes in the way products are manufactured, distributed, consumed, and recovered. The integration of CE principles in SSCM has been evaluated as having potential utility for industries, cities, and businesses in general. Conclusions: Finally, an agenda was identified with suggestions for further research, which can aid researchers and practitioners acting in this field. Managers can obtain insights to improve supply chain sustainability and consequently respond to the challenges imposed by the current pandemic.
\end{abstract}

Keywords: circular economy; sustainable supply chain management; integrative literature review

\section{Introduction}

The management of organizations presents ongoing obstacles, and the current moment is even more challenging in the face of the COVID-19 pandemic. In March 2020, the World Health Organization declared this pandemic as a global problem [1].

Based on projections of significant negative impacts on the global gross domestic product [2], some scientists have identified opportunities to rethink humanity after the pandemic. However, questions are raising about our ability to, after the pandemic, modify the current economic system [3] to adopt a system capable of ensuring the equitable distribution of prosperity, holistically rethinking the use of natural resources, food production, and fundamental transformations in the industrial sector [4].

A transformation in people's lives is underway. The need to change behavior when purchasing products [5], consuming food [6], and using transportation systems [7] inevitably require changes on organizational decisions. For instance, within companies, measures need to be taken regarding transportation, storage, use of productive capacity, sourcing of raw materials, and practically all activities involving logistics and supply chain management [8].

Sustainable Supply Chain Management (SSCM) considers social, environmental, and economic factors, and according to [9], the pandemic can potentially undermine the wider 
dimensions of sustainability as it forces companies to focus on the financial aspect. Still, the same authors reiterate the importance of studying SSCM to improve the social and environmental performance of supply chains in various sectors of the economy [9]. In this sense, adopting circular economy principles has emerged as an alternative to reduce the negative pandemic impacts. After all, the importance of designing a product with high durability and reducing the use of raw material increases, besides preventing and minimizing the generation of waste [10].

Studies such as the one conducted by [11], posit the following central question: after the pandemic, how will value chains contribute to the transition from a traditional (linear) economy to a circular? Thus, this article aims to analyze the international articles that relate sustainable supply chain management with circular economy in a more holistic and integrative way.

In this way, it collaborates to fill the research gap raised by [12]. They pointed out that despite the growing interest in circular economy, there is still a lack of studies that relate the theme to the supply chain management (SCM) field. They also identify a lack of studies that investigate the interrelationship between these sustainable SCM and CE, calling for more research to raise awareness about the advantages of $\mathrm{CE}$, not only by scholars investigating SCM issues but also by the wider research community [12].

Other studies contribute in a relevant way in related areas. For instance, some authors understand that we live in a scenario of diffuse demands and therefore choose the fuzzy method to analyze supply chains $[13,14]$. For this, they include in the developed model variables such as service level and lead time restrictions, in order to help managers to make choices aimed at reducing transportation costs [13,14].

In this paper, we present original insights in the area by including the concept of circular economy as a lens to analyzing sustainable SCM, as well as considering methodological choices that provide a wider perspective of the subject. The paper also contributes to research community by indicating a recent research agenda derived from relevant extant literature. For managers, the work contributes by discussing barriers of different natures such as technological, legal, or institutional that need to be overcome in order to obtain real gains by uniting the principles of circular economy in the supply chain.

Martins and Pato conducted a tertiary literature review covering 198 systematic literature reviews published between 1995 and 2018 and identified the key supply chain management concepts, sustainability perspectives, and methodological aspects related to SSCM [15]. In addition, Merli and Preziosi analyzed the circular economy body of knowledge, considering 565 articles collected through the Web of Science and Scopus databases, using specific structural dimensions to categorize the existing literature in the topic [16]. These two systematic literature review covered the two topics approached in our paper; however, our study is the first integrative literature review connecting the two topic. Thus, the main contribution of this study we can point out the connection between the topics supply chain management and circular economy and the discussion of the term circular supply chain management.

In addition to this introduction, which contextualizes the topic and presents the research problem and the central research gap to be fulfilled, this article is divided into four more sections. The theoretical background takes care of conceptualizing key terms in the field and demonstrating their importance for the contemporaneity of the subject. Then, the methods section presents the Methodi Ordinatio demonstrating the steps followed to search and filter the papers analyzed and show the inclusion and exclusion criteria used for the integrative literature review (ILR) adopted in the study. The fourth part of this article demonstrates the bibliometric findings and discusses relevant perspectives of analyzed articles. In addition, it identifies a research agenda based on what has been emphasized by the international literature. Finally, the research limitations and contributions are highlighted, suggesting ways to evolve the theme. 


\section{Theoretical Background}

\subsection{Circular Economy (CE)}

Circular economy (CE) is an alternative to the traditional economic model that has proved highly polluting and degrading for natural resources and has negative consequences for society. This alternative would seek the reinsertion in the productive chain of those products that have reached the end of their useful life [17]. By denying the concept of waste, the CE aims to close loops in industrial ecosystems by applying at least the "3Rs" of environmental management: Reduce, Reuse, and Recycle [18].

Basically, by seeking to 'Reduce', companies reduce raw materials and energy consumption. According to the principle of 'Reuse', organizations aim to develop products that are more durable and capable of repair. Finally, 'Recycling' ensures that the material returns to the production process for remanufacturing or other components use. Thus, each of the "3R" contributes to waste generation prevention and reduction [19].

To extend the life of products beyond these three basic strategies, authors expand to " $6 \mathrm{R}$ " and even "10R". For instance, [20] studied the Eco-Industrial Parks as an organization of companies capable of sharing raw materials, energy, and waste. According to the authors, during the construction of an industrial ecology model, "6Rs" must be respected, adding to the first three the logic of 'Recovery', 'Redesign', and 'Remanufacture' [20].

'Recovery' would come through reverse logistics bringing used products back into the supply chain, helping companies to reduce waste and add value to the product again. 'Redesign', in turn, can be either at the product level, aiming to facilitate recycling, for example, or in a broader sense, to obtain a systemic approach of actors and flows redesigning the supply chain for the circular economy [21]. The process of dismantling the product for reuse of components and resale in the secondary market, known as 'Remanufacture', is considered essential for closing the loop in the supply chain, as it creates businesses and integrates actors [22].

Even with product recovery rates around $93 \%$ and recycling rates reaching $79 \%$, the Dutch Ministry of Infrastructure and Environment warns that the consumption of natural resources remains high [23]. One of their reports emphasizes that, in addition to technological innovations, socio-institutional innovations are necessary to reach the "10Rs" that the transition to circular economy requires. In addition to the six mentioned above, the report includes 'Rethinking', 'Repairing', 'Refurbish', and 'Repurpose'. By 'Rethinking', multifunctional or sharable products would be put on the market, while 'Repair' would re-establish its original function, rather than being swapped for a new one. When 'Refurbishment', there would be product updates overcoming the obsolescence issue, and 'Repurpose' gives new functions to the products (or parts of it) that would be discarded [23].

Although the concept of circular economy is not necessarily new, it has gained increasing visibility since China sanctioned public policies that include targets for $\mathrm{CE}$ and the European Union presented guidelines for all countries of the economic bloc [24]. Based on the pioneering spirit of China and Europe, several countries around the world are already studying this paradigm as a way to foster innovations in the sectors of public and private administration. From the circular economic perspective, the article [23] investigated the implementation of reverse packaging logistics in Brazil. The authors emphasized the importance of the government demanding integration of the actors in the fulfilment of the sectoral agreements. In addition, they stated that there is little applicability of the principle of shared responsibility and little effective integration of waste pickers [25].

In short, organizations align themselves with circular economy by seeking to remove as much value as possible from products and their components through a restorative and regenerative system from the design [26]. The adoption of six principles can serve as a guide for public or private organizations to eliminate the concept of waste and maximize the usefulness of products by transferring the material as input in another chain. The ReSOLVE method provides primary and secondary metrics for adopting practices that emphasize Regeneration, Sharing, Optimization, Looping, Virtualization, and Exchange [27]. 
Companies such as Nespresso, Dell, Toyota, Airbnb, and Netflix have already adopted part of these principles and are transforming their customers' lives positively, minimizing social and environmental impacts [27].

The concept of circular economy has received attention from public policymakers, managers, and scientists [25], mainly because it helps undo the idea that the economic growth implies damages of the environment. This comprehension represents a minimum condition for achieving sustainability [28]. The circular economy principles are ambitious in going beyond sustainable practices in the supply chain. Still, the constant pursuit of these practices is essential for the transition toward the circular economy [29].

\subsection{Sustainable Supply Chain Management (SSCM) and Circular Economy (CE)}

Supply chain management is defined as the grouping of three or more organizations, which may be suppliers or final customers interconnected by means of products or services and information. An efficient coordination is necessary, mainly if these organizations are located in different locations around the world. With proper long-term management, performance tends to improve for all supply chain participants [30].

In recent years, supply chain managers have worry about issues related to sustainability. As stakeholders are demanding that organizations pay attention to their operations environmental and social issues, these managers occupy a position that may positively or negatively impact operations [31]. The search for introducing the concept of sustainability into the supply chain led [32] to carry out a literature review to understand how economic, environmental, and social performance takes place in the context of the supply chain. The supply chain's participants themselves can take actions to reduce packaging, improve the conditions of employees in warehouses, use transport more efficiently, and demand that suppliers carry out environmental and social programs [32].

According to [33], researchers often confuse sustainable supply chain management (SSCM) with green supply chain management (GSCM). The author explains the mistake by explaining that many economies have already overcome social issues such as forced labor, analogous to slavery or child labor, which is why they focus on environmental issues. However, it is noteworthy that there are still countries with social problems (mainly in the southern hemisphere of the planet), and therefore, it is worth explaining GSCM as a step toward reaching SSCM, which incorporates the balance between the economic, environmental, and social pillars [33].

Sustainable supply chain management seeks to break the barrier that only monetary targets related to operational efficiency and cost reduction [34]. Environmental and social issues should also be included. After all, experts state that this model contributes to acting in a scenario of the scarcity of natural resources and helps stakeholders enhance their performance in other areas, which are being increasingly charged [29].

Regarding the advancement of supply chain management and research, [9] point out that after the pandemic, supply chains will undergo changes, more regional, consumers seeking shorter chains and even participating directly in production, opening space for government interference. Therefore, it is understood that the SSCM will have to face several post-pandemic challenges, mainly from the perspective of sustainable consumption.

The idea of making a supply chain more circular would therefore be the construction of a complex system of relationships that is determined to make the production cycle slower, narrower, and closed [35]. The systematic literature review carried out by these authors highlights that it is necessary to create, capture, and transfer value between the agents in the chain to have positive managerial implications. Waste management, post-sale and post-consumption reverse logistics, as well as product upgrades and promotion actions, are fundamental instruments in this more circular model [35].

In the review carried out by [12], the authors discuss each of the eight main supply chain management processes, relating them to the five principles of circular economy identified in the literature. According to this paper, circular economy has not yet achieved the deserved prominence in journals in operations and logistics, which indicates a pioneering 
spirit for those who publish works that relate the theme to supply chain management. In the opinion of these authors, literature reviews that work at the intersection of themes would be helpful to understand the way scientists are trying to provide solutions to the challenges that organizations currently face [12].

As a scientific contribution, this work provides a list of further research to inspire researchers to advance in scientific knowledge, suggestions contained in the main papers on the subject. Additionally, for academics, this work is relevant because it demonstrates a new search protocol, already tested, but not yet used in reviews that relate the themes studied. Finally, even though this is a theoretical discussion, there are still no studies that discuss the opportunities and challenges of implementing the CE in the supply chain, in this context of the post-pandemic of COVID-19.

\section{Materials and Methods}

From the point of view of its objective, this study can be categorized as descriptive. According to its approach, it is qualitative and from the technical procedure perspective, it is a literature review. Webster and Watson state that two main categories of literature reviews exist: (i) reviews of a mature topic, with an accumulated body of research exists that needs analysis and synthesis and (ii) reviews of emerging issue that would benefit from exposure to potential theoretical foundations [36]. In our case, we deal with two topics: sustainable supply chain management that fits the first type of literature review and circular economy, which fits the second one. However, the novelty involved in our study is the trial to conjugate these two topics in order to analyze their relations. Tranfield, Denyer and Smart point out that the knowledge in the management and organizational studies is fragmented, and there are many challenges to applying the findings in practice. Thus, the authors highlight the need to systematize, locate, and integrate information sources from many subfields to integrate them logically [37].

In addition, [38] stated that there are three main types of literature review, in terms of methodological design: (i) the narrative literature review, which does not make explicit the criteria to include or exclude some materials; (ii) the systematic literature review, which is replicable and explicitly shows the criteria to include or exclude materials, considering just empiric studies to be analyzed; and (iii) the integrative literature review, which is similar to systematic one, making the criteria to select and filter papers explicitly, considering the theoretical ones along with the empiric studies. Our paper fits in the last type of literature review.

Denyer and Tranfield state that a systematic review is entirely different from a traditional literature review because it explores a clearly specified question and detail the steps related to the processes of search and filtering of the papers [39]. According to Souza, Silva and Carvalho, unlike the systematic review and meta-analysis, an integrative review allows the inclusion of experimental and nonexperimental studies; this is the single difference between this type of revision and the systematic one [40]. By analyzing the theoretical and empirical literature together, we seek to understand the phenomenon not only through the definition of concepts and theoretical reviews but also through practical cases where the problem occurs.

The literature review carried out is considered integrative also because after raising the most relevant papers on the subject, we sought to present the main convergent and divergent points. According to Cooper, this type of literature review tries to identify gaps left in the investigations already carried out, and thus direct future research on the theme [41].

The two key subjects of this research are: circular economy (CE) and sustainable supply chain management (SSCM). In order to systematize the steps of our study, we elected the protocol proposed by [42], which is composed by well-defined steps to search, select, filter, and analyze the papers. The first step is related to establish the intention of the study, which was: How is the connection of the topics sustainable supply chain 
management (SSCM) with circular economy (CE), based in the international literature for the past ten years.

The second step is the definition of the criteria of inclusion and exclusion of the papers. We chose to use the Web of Science and Scopus databases to have access to international articles on both topics. These two databases are multidisciplinary and cover the main high impact journals dealing with the topic addressed. According to [43], these databases are the broadest, in addition to having a classification of journals in terms of productivity, number of citations and, especially, the impact of these journals. Harzing and Alakangas emphasize the importance of these databases by providing stability and coverage of publications, in addition to showing an increase in the number of publications [44].

After selecting the databases, the keywords to conduct the searches were selected. We used two sets of keywords: "Circular Economy" and "Sustainable Supply Chain" with the Boolean operator "AND". We highlight that we searched the articles published between 2010 to 2020 because we found two relevant literature reviews about the topics addressed in our study that provide evidence that the publications on sustainable supply chain management, which is a consolidated topic, are decreasing from 2010 [15]. On the other hand, the circular economy can be considered as an emerging topic, with a growing interest of publication mainly from 2009/2010 [16]. These two literature reviews were conducted following systematic protocols trying to exhaust the existing literature on the topics. In terms of type, we select only documents classified as full papers published in journals in the English language. Consequently, we exclude the review papers, chapters and books, editorial material letters, and conference proceeding papers.

As the third step, we conducted a preliminary search and reading to analyze if the papers fits the scope of our study and the results were: (i) 30 scientific articles on the Web of Science and (ii) 37 articles on Scopus, totaling 67 articles on the themes under study. As the fourth step, after this first identification and filtering process, one article was excluded for being in the Chinese language and 20 articles were duplicated. This filtering process resulted in 46 articles with potential for analysis.

In order to distinguish the most relevant articles on CE and SSCM, the Methodi Ordinatio was used. Previous studies already used this protocol of SLR [45-47]. This protocol is replicable and present systematic steps to select, filter, and analyze the papers. In the fifth step, we search for the JCR-Journal Citation Report impact (2018) factor of the journals related to the 46 papers, the number of citations considering the Google Scholar data and the year of publication. Thus, these data were inserted in a spreadsheet with the equation of InOrdinatio, which is an index to rank the papers from the best to the worst.

This methodology aims to classify the papers selected in the literature review in order of relevance, considering a multicriteria perspective, with three main criteria: year of publication, citations, and impact factor. Recent studies have used and recommended the protocol, such as $[47,48]$. After all, the InOrdinatio equation helps the researcher to rank the papers to find the most relevant articles, considering the three elements cited above.

Equation 1 takes the following into consideration: (i) the impact factor of the journals (ii) the year of publication of the articles and (iii) the number of citations of the articles. Pagani, Kovaleski and Resende indicates the importance of the researcher to define an index at the end of the ranking [42].

$$
\text { InOrdinatio }+\left(\frac{I F}{1000}\right)+\alpha *[10-(\text { Research Year }- \text { Publish Year })]+(\varepsilon \text { Ci })
$$

The present paper was limited to the articles that obtained the InOrdinatio index greater than or equal to 95.0, and thus ended this stage with 38 selected articles. As indicated by [42], researchers are free to define how many to analyze, according to their priorities. We decided to stop at these 38 papers. Finally, the titles, abstracts, and keywords were analyzed. We excluded one more paper because it did not have adherence with the theme, and, therefore, the amount of 37 articles were analyzed (Appendix A). 
In the sixth step, it was conducted the complete reading of the 37 articles selected from two perspectives. In the first, under a quantitative approach, the objective was to measure and describe the bibliometric information, to present the evolution of publications over time, identification of journals, authors, and institutions that have more publications that relate to the themes. In the second perspective, through a qualitative approach, the contents of the prevailing articles will be discussed and compared in order to organize a research agenda [49] to stimulate the continuity of research on sustainable supply chain management and circular economy. Figure 1 briefly presents the methodological path used in the research.

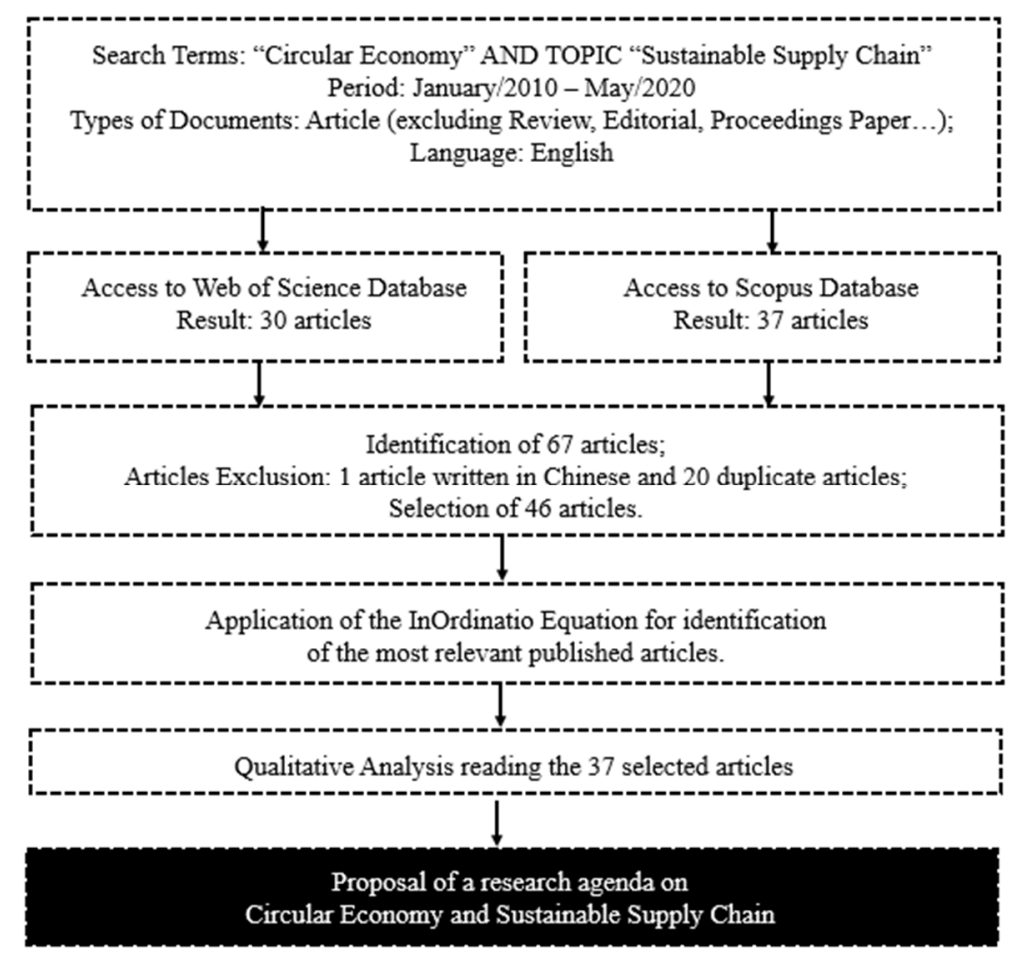

Figure 1. Methodological path of the research.

Regarding the authors that compose the sample of this literature review, a relationship network was created using Ucinet 6 for Windows Software. According to [50], a network like this helps to identify connections between authors who have an affinity in research interests. Known as a social network, this interaction can be visually represented through graphics [51].

From the titles and keywords of the 37 articles, we created two word clouds. This type of graph helps lexical analysis, the words are grouped according to their frequency [52]. Two word clouds will be presented in the following section: one of the words found in the titles and one of the keywords. After classifying the present literature review, naming the protocol used, describing the inclusion and exclusion criteria, and detailing the methodological path taken, the next section will present and discuss the results obtained.

\section{Analysis and Discussion of Results}

In this section, the analysis and discussion of the results obtained in the research begin. Figure 2 shows the evolution of publications on circular economy and sustainable supply chain management from 2010 to 2020 . It is possible to observe that two articles were published in the years 2010 and 2011, one each year. As of 2017, an increase in publications began, with 5, 7, and 17 articles published in 2017, 2018, and 2019, respectively. It should be noted that the search was conducted in May 2020; therefore, not all publications considered all publications for the year 2020. 


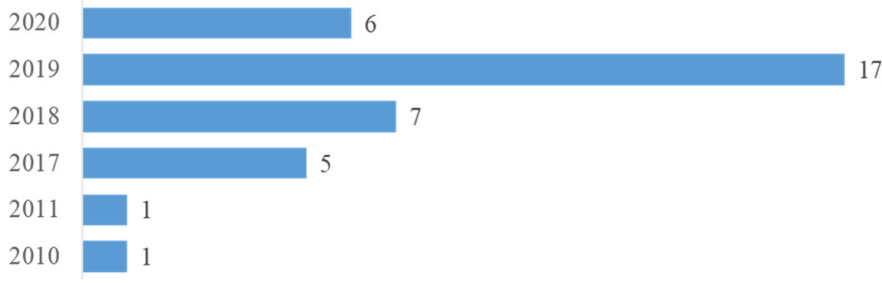

Figure 2. Evolution of publications.

One of the possible explanations for the growth in researchers' interests is the work done by a nongovernmental organization called the Ellen MacArthur Foundation (EMF). In partnership with World Economic Forum, member companies such as Coca-Cola, Nestlé, and Philips in 2014, the EMF launched a publication entitled "Towards the Circular Economy: Accelerating the scale-up across global supply chains". By presenting the limits of a linear economy, the existing logistics bottlenecks and the benefits of adopting circular strategies, this technical work invites companies, governments, and research institutions to join forces so that the $\mathrm{CE}$ gains global proportions through the transformation of supply chains [53]. Given the importance of the topic, in 2015, the European Environment Commission presented 54 actions toward a circular economy [54].

Given the scope of this research, we identified 15 journals with publications on the subject. Among these journals, only four do not have JCR. Table 1 shows the seven journals with more publications. The Journal of Cleaner Production stands out, which has 14 published articles that mix CE and SSCM. In literature reviews involving the circular economy, such as those of [55-58] also identified this journal as the main responsible for scientific dissemination on the subject. The International Journal of Production Research, Management Decision and Resource, Conservation \& Recycling also has relevant participation, with three articles belonging to the sample of this research.

Table 1. The journals with more publications on the theme.

\begin{tabular}{ccc}
\hline $\mathbf{N}^{\mathbf{0}}$ & Journal & Amount \\
\hline 1 & Journal of Cleaner Production & 14 \\
2 & International Journal of Production Research & 3 \\
3 & Management Decision & 3 \\
4 & Resources, Conservation \& Recycling & 3 \\
5 & Journal of Manufacturing Technology Management & 2 \\
6 & Production Planning \& Control & 2 \\
7 & Sustainability & 2 \\
- & Others journal & 8 \\
& Total Publications in Journals & 37 \\
\hline
\end{tabular}

The 37 articles published are linked to 121 different authors, who stand out as authors or coauthors (Table 2): Charbel José Chiappetta Jabbour with five articles; Ana Beatriz Lopes de Sousa Jabbour with four articles; Joseph Sarkis, Abraham Zhang, and Muhammad Farooque with three articles for each author.

Table 2. The authors with more publications on the subject.

\begin{tabular}{ccc}
\hline $\mathbf{N}^{\circ}$ & Authors & Amount \\
\hline 1 & Charbel Jose Chiappetta Jabbour & 5 \\
2 & Ana Beatriz Lopes de Sousa Jabbour & 4 \\
3 & Joseph Sarkis & 3 \\
4 & Abraham Zhang & 3 \\
5 & Muhammad Farooque & 3 \\
\hline
\end{tabular}


The first two authors are frequent partners and, in one of the scientific articles, include Joseph Sarkis, who also presents himself as productive. In [59], they aim to fill a research gap: the management of human resources and the social side, which have been little engaged in the circular economy literature. That is why they conducted a literature review in which they raised state of the art on the human side in organizations that develop the circular economy. In addition, they present a framework and a research agenda contributing to theoretical development. Finally, we pointed out that this study demonstrates the relationship between the quality of training of employees and the proper functioning of the sustainable supply chain [59].

These 121 authors are linked to 77 different universities around the world. The four research institutions with the most links with the authors are presented in Table 3 below. It is possible to identify that Montpellier Business School is the university with the most links to the authors, Charbel José Chiappetta Jabbour, and Ana Beatriz Lopes de Sousa Jabbour associated with this French university.

Similarly, the results of the review on circular economy guided by [57] also found in European countries (such as France and England) the leading institutions that publish on the subject. As shown in Table 3, the other universities are located in New Zealand, Czech Republic, and England, respectively.

Table 3. Institutions that have more links with the authors.

\begin{tabular}{ccc}
\hline $\mathbf{N}^{\circ}$ & Institutions & Amount \\
\hline 1 & Montpellier Business School & 11 \\
2 & Auckland University of Technology & 6 \\
3 & Brno University of Technology & 5 \\
4 & University of Sheffield & 5 \\
\hline
\end{tabular}

Another study published by Montpellier Business School researchers deserve to be highlighted; it analyzed the circular business models in the decision-making processes in operations management, which includes logistics and supply chain. Through a literature review, besides indicating the evolution of the subject, the main authors and methods employed were highlighted. Genovese, Acquaye, Figueroa and Koh list practical applications for managers. They emphasize the importance of creating a system of indicators aligned with the CE (recycling rate, ecoefficiency and circularity), performing solid waste management, integrating reverse logistics, and seeking the construction of industrial symbiosis [28]. Finally, they conclude that the integration among the participants of the chain is essential for the loop model to be included in the organizational decisions that concern the area of operations [28].

Figure 3 shows the relationship network between authors who publish works that relate CE and SSCM. Based on the five authors with more publications, it is possible to identify two networks. The first one, the authors C.J.C. Jabbour, A.B.L.S. Jabbour, and Sarkis are connected with each other; these authors have relationships with other 21 different authors, and they have links with universities located in Brazil, China, UAE, United States, Qatar, and United Kingdom.

Authors A. Zhang and M. Farooque are both part of the same network, which is connected with seven other authors who have links with universities located in China, United States, France, and New Zealand. From the analysis of the network of relationships between the authors (Figure 3), it is possible to conclude that there are two networks that stand out, considering the volume of authors and production of articles; moreover, these authors are distributed in different universities on different continents, which allows us to see the global interest in the themes. 


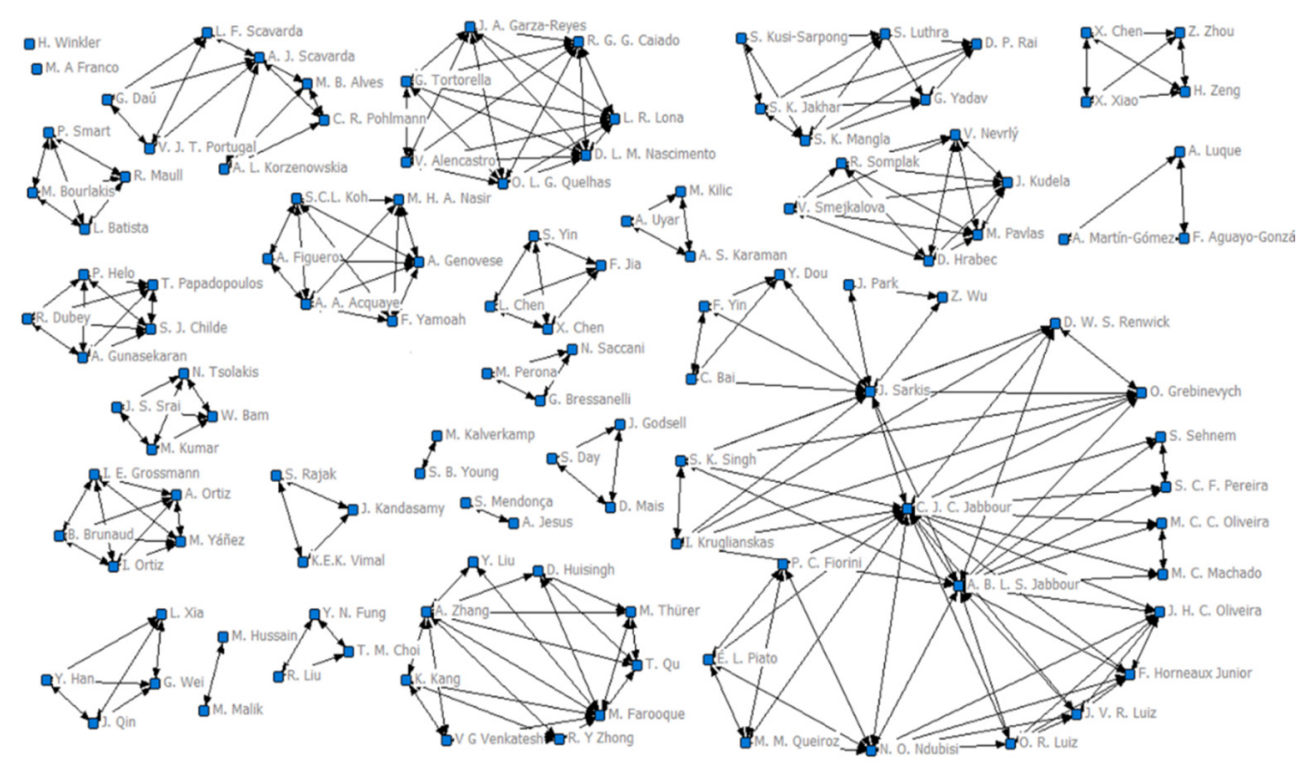

Figure 3. Relationship network between the authors.

The study is the result of the partnership between M. Farooque and A. Zhang and has the highest InOrdinatio is a literature review on Circular Supply Chain Management (CSCM). According to [60], global consumption is too high to guarantee natural resources available shortly. Therefore, severe changes in the way products are manufactured, distributed, consumed, and recovered need to occur as soon as possible. The integration of the $\mathrm{CE}$ philosophy in the management of the supply chain would emerge as the solution for the reduction of the need for virgin materials. As a consequence, the circularity of remanufactured products and the change in the perception of risk and value in consumers can be pointed out [60].

In [61], the authors also perform a theoretical revision work; however, they change the focus of the CSCM to develop a framework that adapts technological tools for product Life Cycle Analysis (LCA). According to the authors, blockchain, big data analysis, and the Internet of Things (IoT) can facilitate sustainable practices in supply chains.. After all, from a permanent record, shareable and actionable by several supply chain participants, the traceability, authenticity, and legitimacy of the products (fundamental for the viability of reverse logistics and the applicability of the $3 R^{\prime}$ s) are obtained [61].

In order to visualize the most recurrent terms in the titles and keywords of the articles, the word cloud tool was used. Two word clouds were created and are shown in Figure 4, below. From your analysis, you can see that the words: Economy, Circular, Chain and Supply stand out in the two word clouds. In the word cloud of the titles, the words management, performance, literature, review, case and framework are highlighted. In word cloud only the keywords are highlighted: sustainable, environmental, closed-loop, industry, green and operations.
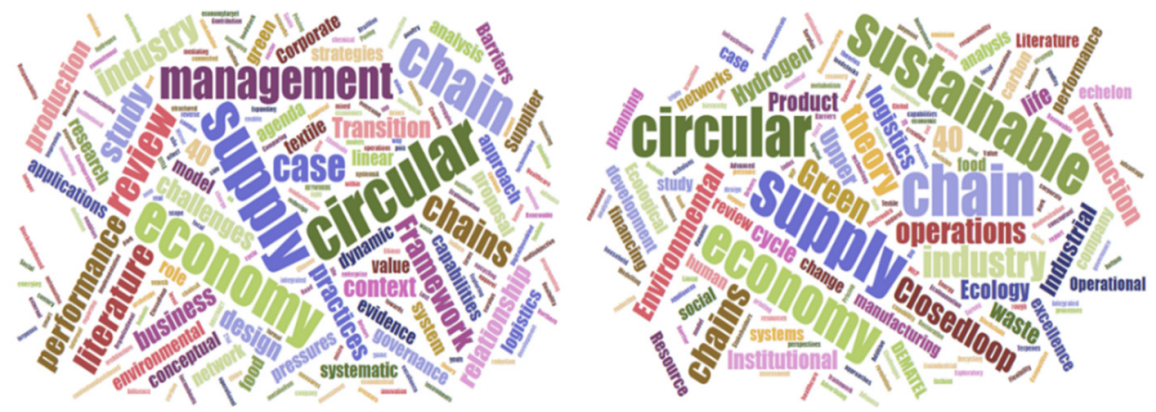

Figure 4. Word clouds of the titles and keywords of the analyzed articles. 
From the analysis of the identified articles, it was possible to observe the themes addressed, which were related to how sustainable supply chain management can contribute to the goals of the circular economy [62]. When addressed about the circular supply chain $[26,60]$, some authors have also dealt with redesigning the supply chain toward a circular economy [21,29,63,64]. Reverse supply chain management was the theme of [65], while [66] investigated supplier relationship management. Two of them focused on waste management $([67,68])$, and [69] addressed green logistics.

We identified issues related to digital transformation and industry 4.0 , specifically big data, Internet of Things (IoT), and blockchain ([63,70-73]). Aspects related to innovation were observed, such as eco-industrial parks [74], capacity for innovation [75], and ecoinnovation [76]. Issues related to human resource management were discussed in [59] and issues about corporate social responsibility were discussed in [63].

Additionally, some of the articles analyzed the structures of circular business models [28,72] or discussed strategic decision making for sustainability [77]. In [28], the dynamic capabilities in supply chains were analyzed, whereas in $[61,64,68]$, the life cycle assessment was applied. Finally, it is worth mentioning that both $[74,78]$ used the institutional theory as a theoretical lens for their work that mixes circular economy and sustainable supply chain.

Regarding the methodological choices used in the analyzed articles, we found that 10 out of 37 articles (27\%) were theoretical and 27 articles (73\%) were empirical. The theoretical-empirical works were applied in several sectors: The electronics industry was analyzed in $[21,62,66,72,74,79]$. The food sector was the subject of research for $[29,60,80,81]$.

The health area was dealt with in $[63,82]$, while some authors focused on the chemical sector $[66,83]$. To address aspects of the circular economy in the supply chain, the authors of $[65,73]$ paid more attention to the automotive industry, while the authors of $[77,84]$ investigated the textile field.

Areas such as civil construction, wood, and furniture were also addressed [64,71,74], as were oil and gas in [85]. Finally, it is crucial to emphasize that the public area was studied in [67] and agricultural production was studied in [81].

In addition to theoretical-empirical research, several literature reviews were identified [21,28,55,59,63,76,80,85-88]. Others carried out the literature review first to subsequently conduct an analysis of documents available by organizations $[69,77,81]$.

Regarding the research participants, several actors participated in these investigations. Purchasing managers participated in $[62,65]$, while in $[21,84]$ environmental and sustainability managers were heard. The quality control manager contributed to [62] and [80] and the general manager contributed to $[60,62,74,81]$.

The experience of CEOs or company founders was significant in [21,60,74,84]. Marketing, innovation, or sales managers participated in investigations guided by [21,84]. Finally, engineers, professors, and technical specialists participated in research such as those of $[72,83]$.

Regarding the methodological choices, multicriteria methods were used, such as Decision Making Trial and Evaluation Laboratory-DEMATEL and ÉLimination et Choix Traduisant la REalité-ELECTRE [60,62,73]. Mathematical models were executed in [67,89]. Regression analysis [66] (Dubey et al., 2019) and structural equation modeling [75,85] were also performed.

The article best evaluated by InOrdinatio's ranking represents a theoretical-empirical work of outstanding quality (to be verified by the number of citations - 409 until the moment of finishing this paper). From the question "how to improve sustainable supply chain management to align with the concept of circular economy?", ref. [29] compared the performance of a traditional production system with a circular one.

To conduct this analysis, the authors first made a theoretical search, then a documentary analysis to obtain environmental data from UK industries (such as solid waste generation and air emissions) to conduct two case studies finally. The first study was applied to the chemical industry and the second one analyzed the production of biodiesel from cooking oils. Among the findings of the study by [29], the assertions that the transition 
to a sustainable economy is challenging, primarily due to its economic viability, stand out. However, they are also adamant that sustainable supply chain management contributes to building a competitive advantage and brings direct and indirect environmental benefits [29].

Among the articles analyzed, it was identified that seven articles (19\%) used mixed methods, that is, quantitative and qualitative; seven papers (19\%) used only quantitative methods and, the predominance of articles that use qualitative methods, totaling 23 articles $(62 \%)$. Park, Sarkis and $\mathrm{Wu}$, in their pioneer article investigated qualitatively challenges and opportunities that organizations can obtain when seeking a balance between financial gain and environmental protection. At the time of publication of this work (2010) and the locus of the research (China) was in the initial phase of implementing the Circular Economy [79].

In investigating three companies in the Chinese electronics industry, the study by [79] found that while managers are concerned about long-term environmental challenges, they are not willing to have high costs in the short term to remain environmentally friendly. Regarding collective participation in the business, they found that the integration of the CE elements at different points of the supply chain added value to the business, not only at the micro level (of the individual organizations) but also at the meso level, throughout the chain and in the industrial parks [79].

Papers that unite CE and SSCM themes usually have practical and managerial contributions. After all, they show managers of different organizations that they must be aware of the issues of green products and services, available renewable resources and available green suppliers. As [62] summarizes, gains for several actors are perceived when directing a sustainable supply chain towards a circular economy.

Concerning environmental aspects, collaboration towards the best environmental practices in supply chains can positively impact in two ways, first, through formal ways, such as environmental contracts and standards, or second in informal ways, such as the relationship of trust and cooperation between the actors in the chain [82].

The managerial implications exposed by [26] highlight the importance of managers being prepared to maintain the coordination of traditional supply chains for restorative/regenerative ones towards a circular supply chain. For this to occur, managers must fully know the concept of circular economy [81].

Managers directing their actions towards the circular economy may face potential barriers, in addition to guide possible solutions for these barriers; making it possible to adequately prepare for the transition to occur at the lowest cost and maximize results in various aspects $[21,73,76]$. It is possible to identify the potential barriers to be faced, in addition to guiding possible solutions for these barriers, making it possible to adequately prepare for the transition to occur at the lowest cost and maximize results in various aspects. The main barrier according to [60] is the lack of collaboration between actors in the supply chain.

In this sense, $[81,90]$ reinforce the importance of collaboration between the links in the supply chain towards the sustainability of the entire chain. Corroborating, [91] highlight the importance that actors in the same supply chain should incorporate aspects of sustainability seeking better results and the prospect of the circular economy.

For organizations that aim to migrate from a linear economy to a circular economy must be aware that their products and processes must undergo significant changes [75]. According to [90], the information technology era can significantly contribute to the formation of sustainable supply chains, and these changes can happen through industry 4.0 [72].

Reinforcing the aspect of industry 4.0, the managerial contributions presented by [70] highlight the importance of managers using big data to build a sustainable supply chain. Still, such action is seen as a challenge to be overcome by organizations. Short of technological aspects, ref. [72] highlights the importance of changing the culture within these organizations, promoting a culture of reuse and recycling in processes. 
Furthermore, for [66] it is necessary the participation of the strategic level in the direct relationship with suppliers concerning sustainable practices. They need to encourage suppliers to adopt such practices, actions such as a workshop and offering training to suppliers' employees are practices well seen.

From the findings, it is possible to observe that the circular economy can effectively contribute mainly in the environmental aspect to a sustainable supply chain; the economic factors are highlighted. However, according to [59] warns, it is necessary to research more about the human side of the supply chain, which can stimulate or inhibit actions aimed at the circular economy.

Following, Table 4 shows the leading suggestions of later research, built from the qualitative analysis of the 37 articles that composed the present work.

Table 4. Research agenda for circular economy and sustainable supply chain management.

\begin{tabular}{|c|c|c|}
\hline $\mathbf{N}^{\mathbf{o}}$ & Further Research Suggestions & References \\
\hline 1 & $\begin{array}{l}\text { To carry out case studies to investigate the circular production system; } \\
\text { To develop environmental and economic indicators to compare linear and circular chains. }\end{array}$ & [29] \\
\hline 2 & $\begin{array}{l}\text { To develop models to quantify relationships within and between organizations in an } \\
\text { CE environment; } \\
\text { To formulate frameworks to help model flows in the SSCM. }\end{array}$ & [79] \\
\hline 3 & $\begin{array}{l}\text { To describe which factors are helping and which are hindering the CE. } \\
\text { To present empirical evidence of the real value of CE transformation. }\end{array}$ & [76] \\
\hline 4 & Empirically apply the sustainable supply chain networks concept & {$[68]$} \\
\hline 5 & $\begin{array}{l}\text { To apply the conceptual model designed to explore in different countries the effects of } \\
\text { institutional pressure on the SSCM and how it influences the viability of the CE. }\end{array}$ & [74] \\
\hline 6 & $\begin{array}{l}\text { To investigate the future of CE implementation at the micro level and to extend literature on } \\
\text { sustainable entrepreneurship, product design for sustainability, closed loop supply chains, } \\
\text { green marketing, collaborative innovation for sustainability among other circular strategies. }\end{array}$ & [84] \\
\hline 7 & $\begin{array}{l}\text { Examining the impacts of CE business models on the development of Human Resource } \\
\text { management practices in an organization. } \\
\text { Conducting case studies aimed at deepening the presented framework, providing insights on } \\
\text { which Human Resource management practices are oriented to the CE and how and why they } \\
\text { impact organizational performance. }\end{array}$ & [59] \\
\hline 8 & $\begin{array}{l}\text { To Assess the importance of sustainable packaging design and product labeling for the } \\
\text { circular supply chain management (CSCM) }\end{array}$ & [87] \\
\hline 9 & $\begin{array}{l}\text { Consulting the opinions of experts and managers in order to understand the decision making } \\
\text { process of operational management (logistics/supply chain) for adopting circular } \\
\text { business models. } \\
\text { Analyze the critical success factors and consider the necessary changes in operational } \\
\text { management decision making (logistics/supply chain), taking different national } \\
\text { infrastructures for the implementation of the CE into account. }\end{array}$ & [28] \\
\hline 10 & $\begin{array}{l}\text { Consulting experts and managers from developing countries to raise the specific challenges } \\
\text { of each place in order to encourage the adoption of sustainability in supply chains. }\end{array}$ & [73] \\
\hline 11 & $\begin{array}{l}\text { Conduct empirical research on circular supply chain management, as the field is promising. } \\
\text { Analyze the impact on the economic issue, because is seen as a barrier that can } \\
\text { hinder circularity. }\end{array}$ & {$[29,87]$} \\
\hline 12 & $\begin{array}{l}\text { Estimate economic gains through circular operations towards a sustainable supply chain. } \\
\text { Apply the model in other contexts to verify its effectiveness. }\end{array}$ & [89] \\
\hline
\end{tabular}

Going beyond gathering suggestions from other authors in a table, this research guides researchers to other ways of relating the themes of the circular economy with sustainable management of the supply chain. Empirically, cases implementing circular practices in the supply chain must be observed in individual organizations (micro level), in the set of industries (meso level) and/or in entire cities (macro level). If feasible, we 
suggest comparing successful cases with cases in the implementation stage, including in different countries.

Based on other papers, we realized the need to include actors who often do not have a voice in decisions in the chain, but who often perform important work. Still criticizing the articles already published, the lack of theories that support studies involving CE and SSCM is also a problem raised. Therefore, we suggest that further research include actors and make use of administrative theories such as institutional theory or stakeholder theory to support the discussion.

Many supply and communication problems can now be solved with the help of technology. The trend is for terms related to industry 4.0 to grow in studies in the area, especially blockchain, internet of things and big data. Therefore, we suggest that further investigations use qualitative and quantitative methods to analyze processes of dematerialization, digitization and supply chain optimization.

There is not only a field for studies involving technology but also human resources management. The environmental education process for transforming leaders with the capacity to implement innovative practices still needs to be studied and, therefore, the gap remains open. Finally, studies that direct attention to the public area (government/state/ municipality) deserve attention, as well as the strategies that the public sector can adopt to contribute to this transition.

The scenario of uncertainties can change collaboration relationships and, consequently negatively interfere in the partner network and in the supply of product and raw materials. Therefore, quantitative studies such as [92] can be useful to help industry managers to validate these relationships raised in this theoretical study.

With the results obtained in this research, it was possible to note that the themes circular economy and sustainable supply chain management complement each other. Thus, they are deserving the attention of scholars and practitioners acting in the field. Even with the research findings, it is possible to observe a fertile area for future research and, thus, the discussions about the themes are far from exhausting.

\section{Final Considerations}

The high level of consumption that the world's population has maintained over the past decades has left scientists worried about the depletion of natural resources. Pandemics like that of COVID-19 exemplify the drastic consequences that local actions can bring to all humanity. In this way, the need to rethink the way products are produced, marketed, distributed, consumed and recovered accelerates.

Sustainable supply chain management (SSCM) can implement ecological innovations that would collaborate to preserve the environment. Even more broadly, the circular economy (CE) emerges as a component for sustainable development, as it involves activities such as repair, reuse, refurbishment, and recycling. Thus, we conducted an integrative review of the international articles that relate the SSCM with CE.

Following the methodological path proposed in the research (Figure 1) and filtering according to the indexes calculated through InOrdinatio, it was possible to identify the 37 most relevant articles. It was identified that the first publications occurred in 2010 and 2011 and only in 2017 had new publications and, from that year on, there was a significant increase in publications (Figure 2). The journal that most contributed to disseminating scientific content on the themes was the Journal of Cleaner Production (Table 1).

The results presented in Table 2 recognize the main author as "Charbel José Chiappetta Jabbour" and the five most prolific authors are part of 3 networks of relationships (Figure 3), to which they are connected with researchers operating on several continents, thus demonstrating the dissemination of knowledge on the subject (Table 3). Additionally, the most used terms in the titles and keywords of the articles were presented in word cloud format (Figure 4), which allows an overview of the discussion.

Outstanding articles had their content discussed, which generated findings on the correlation between the themes, leading this article to the achievement of the proposed ob- 
jective. For researchers as well as for managers are positive contributions of this study. We have prepared a list with the main indications for future studies for academic researchers, based on the reading and qualitative analysis of the 37 most relevant articles for the area (Table 4). For industry managers', they should be concerned with developing products capable of being disassembled, with recoverable and/or recyclable components. If possible, digitize products or transform them into services; after all, dematerializing is a trend.

For public and private managers, the results of this research recommend the integration of CE principles in SSCM to prevent interruptions in the supply of raw materials and strategic products. Technical, cultural, financial and institutional barriers need to be overcome, but opportunities for legal, environmental, and competitive advantage gains are identified for organizations seeking to build a restorative and regenerative business model.

Other relevant findings indicate that more sustainable supply chains tend not only to contribute to individual organizations but also to the competition of the set of participating industries. In other words, sustainable supply chain management can positively influencing the micro and meso levels of the Circular Economy. It is also worth emphasizing the importance of human resources for implementing circular practices within the firm or between firms. Thus, in addition to the efficiency, marketing and legal gains already mentioned, the articles analyzed by this review induce confirmation that by implementing the EC ideas, the supply chain tends to reduce risks and increase resilience.

This research presents the following limitations and, consequently, also offers opportunities for future work: (i) the research took into consideration only the Web of Science and Scopus databases and the keywords "Circular Economy" and "Sustainable Supply Chain". Therefore, it is suggested that future research studies include other databases and that other keywords be used that may be related to the subject, such as "Green Supply Chain" and "Circular Supply Chain"; (ii) in the relationship network, only the authors were taken into consideration. (iii) Considering that the protocol Methodi Ordinatio can filter some papers, we recommend that future research compare the results with another protocol and consider different period of publication and databases to extend the analysis. It is known that networking is possible considering the institutions the authors are linked to and the countries where these institutions are located, as well as the use of other software for networking, for example, VOSViewer.

Although a perfect circularity of products on a large scale is virtually impossible, the principles of the $\mathrm{CE}$ represent opportunities to bring environmental, social and economic benefits to supply chains. Theoretical contributions such as this one symbolize an incentive for further research on the challenges and possible benefits of circular economy in sustainable supply chain management, especially for developing economies. This paper can be helpful for researchers and practitioners acting in this field of knowledge by synthetizing the state-of-art literature on the topic. Finally, the paper's main contribution lies in connecting two subjects, one already consolidated which is the supply chain management concept. The other one is considered still as an emerging topic, which is the circular economy. The paper innovates by discussing the concept of circular supply chain management, which is a topic exploited by few.

Author Contributions: J.A.C.-S. and G.Y.E. gathering of bibliometric data, conducting the integrative literature review, in addition to analysis and writing of the original draft preparation. P.G. and L.B. contributed in the writing, review and translation into English language. All authors have read and agreed to the published version of the manuscript.

Funding: This research received no external funding.

Institutional Review Board Statement: Not applicable.

Informed Consent Statement: Not applicable.

Conflicts of Interest: The authors declare no conflict of interest. 


\section{Appendix A}

Table 1. List of analyzed articles, we ordered according to the Methodi Ordinatio criteria.

\begin{tabular}{|c|c|c|c|c|c|c|c|}
\hline Order & Paper & Reference & FI & Year & $\mathrm{Ci}$ & InOrdinatio & References \\
\hline 1 & $\begin{array}{l}\text { Sustainable supply chain management } \\
\text { and the transition towards a circular } \\
\text { economy: Evidence and } \\
\text { some applications }\end{array}$ & Omega & 5341 & 2017 & 409 & 484 & [29] \\
\hline 2 & $\begin{array}{l}\text { Creating integrated business and } \\
\text { environmental value within the context } \\
\text { of China's circular economy and } \\
\text { ecological modernization }\end{array}$ & $\begin{array}{l}\text { Journal of Cleaner } \\
\text { Production }\end{array}$ & 6395 & 2010 & 228 & 234 & [79] \\
\hline 3 & $\begin{array}{l}\text { Lost in Transition? Drivers and Barriers } \\
\text { in the Eco-innovation Road to the } \\
\text { Circular Economy }\end{array}$ & Ecological Economics & 4281 & 2018 & 150 & 234 & [76] \\
\hline 4 & $\begin{array}{l}\text { Closed-loop production systems-A } \\
\text { sustainable supply chain approach }\end{array}$ & $\begin{array}{l}\text { CIRP Journal of } \\
\text { Manufacturing Science } \\
\text { and Technology }\end{array}$ & 2333 & 2011 & 170 & 182 & [68] \\
\hline 5 & $\begin{array}{l}\text { Comparing linear and circular supply } \\
\text { chains: A case study from the } \\
\text { construction industry }\end{array}$ & $\begin{array}{l}\text { Int. J. Production } \\
\text { Economics }\end{array}$ & 4998 & 2017 & 103 & 178 & [64] \\
\hline 6 & $\begin{array}{l}\text { Institutional pressures, sustainable } \\
\text { supply chain management, and circular } \\
\text { economy capability: Empirical evidence } \\
\text { from Chinese eco-industrial park firms }\end{array}$ & $\begin{array}{l}\text { Journal of Cleaner } \\
\text { Production }\end{array}$ & 6395 & 2017 & 89 & 165 & [74] \\
\hline 7 & $\begin{array}{l}\text { Circular economy at the micro level: A } \\
\text { dynamic view of incumbents' struggles } \\
\text { and challenges in the textile industry }\end{array}$ & $\begin{array}{l}\text { Journal of Cleaner } \\
\text { Production }\end{array}$ & 6395 & 2017 & 79 & 155 & [84] \\
\hline 8 & $\begin{array}{l}\text { Supply Chain Configurations in the } \\
\text { Circular Economy: A Systematic } \\
\text { Literature Review }\end{array}$ & Sustainability & 2592 & 2017 & 72 & 145 & [88] \\
\hline 9 & $\begin{array}{l}\text { Who is in charge? A review and a } \\
\text { research agenda on the 'human side' of } \\
\text { the circular economy }\end{array}$ & $\begin{array}{l}\text { Journal of Cleaner } \\
\text { Production }\end{array}$ & 6395 & 2019 & 46 & 142 & [59] \\
\hline 10 & $\begin{array}{l}\text { Exploring Industry } 4.0 \text { technologies to } \\
\text { enable circular economy practices in a } \\
\text { manufacturing context: A business } \\
\text { model proposal }\end{array}$ & $\begin{array}{l}\text { Journal of } \\
\text { Manufacturing } \\
\text { Technology } \\
\text { Management }\end{array}$ & 2642 & 2018 & 47 & 130 & [72] \\
\hline 11 & $\begin{array}{l}\text { Challenges in supply chain redesign for } \\
\text { the Circular Economy: a literature } \\
\text { review and a multiple case study }\end{array}$ & $\begin{array}{l}\text { International Journal of } \\
\text { Production Research }\end{array}$ & 3199 & 2019 & 28 & 121 & [21] \\
\hline 12 & $\begin{array}{l}\text { Circular economy business models and } \\
\text { operations management }\end{array}$ & $\begin{array}{l}\text { Journal of Cleaner } \\
\text { Production }\end{array}$ & 6395 & 2019 & 21 & 117 & [28] \\
\hline 13 & $\begin{array}{l}\text { Circular supply chain management: A } \\
\text { definition and structured }\end{array}$ & $\begin{array}{l}\text { Journal of Cleaner } \\
\text { Production }\end{array}$ & 695 & 2019 & 20 & 116 & [87] \\
\hline 14 & $\begin{array}{l}\text { In search of a circular supply chain } \\
\text { archetype - a content-analysis-based } \\
\text { literature review }\end{array}$ & $\begin{array}{l}\text { Production } \\
\text { Planning \& Control }\end{array}$ & 3340 & 2018 & 32 & 115 & [86] \\
\hline 15 & $\begin{array}{l}\text { Supplier relationship management for } \\
\text { circular economy Influence of external } \\
\text { pressures and top management } \\
\text { commitment }\end{array}$ & Management Decision & 1963 & 2019 & 22 & 114 & [66] \\
\hline 16 & $\begin{array}{l}\text { A framework to overcome sustainable } \\
\text { supply chain challenges through } \\
\text { solution measures of industry } 4.0 \text { and } \\
\text { circular economy: An automotive case }\end{array}$ & $\begin{array}{l}\text { Journal of Cleaner } \\
\text { Production }\end{array}$ & 6395 & 2020 & 3 & 109 & [73] \\
\hline 17 & $\begin{array}{l}\text { Blockchain-based life cycle assessment: } \\
\text { An implementation framework and } \\
\text { system architecture }\end{array}$ & $\begin{array}{l}\text { Resources, } \\
\text { Conservation \& } \\
\text { Recycling }\end{array}$ & 7044 & 2020 & 2 & 109 & [61] \\
\hline 18 & $\begin{array}{l}\text { Organizational enablers for circular } \\
\text { economy in the context of sustainable } \\
\text { supply chain management }\end{array}$ & $\begin{array}{l}\text { Journal of Cleaner } \\
\text { Production }\end{array}$ & 6395 & 2020 & 1 & 107 & [85] \\
\hline 19 & $\begin{array}{l}\text { The circular economy in the textile and } \\
\text { apparel industry: A systematic } \\
\text { literature review }\end{array}$ & $\begin{array}{l}\text { Journal of Cleaner } \\
\text { Production }\end{array}$ & 6395 & 2020 & 1 & 107 & [55] \\
\hline 20 & $\begin{array}{l}\text { Green logistics performance and } \\
\text { sustainability reporting practices of the } \\
\text { logistics sector: The moderating effect of } \\
\text { corporate governance }\end{array}$ & $\begin{array}{l}\text { Journal of Cleaner } \\
\text { Production }\end{array}$ & 6395 & 2020 & 0 & 106 & [69] \\
\hline
\end{tabular}


Table 1. Cont.

\begin{tabular}{|c|c|c|c|c|c|c|c|}
\hline Order & Paper & Reference & FI & Year & $\mathrm{Ci}$ & InOrdinatio & References \\
\hline 21 & $\begin{array}{l}\text { Improving sustainable supply chains } \\
\text { performance through operational } \\
\text { excellence: circular economy approach }\end{array}$ & $\begin{array}{l}\text { Resources, } \\
\text { Conservation \& } \\
\text { Recycling }\end{array}$ & 7044 & 2019 & 9 & 106 & [81] \\
\hline 22 & $\begin{array}{c}\text { Digitally-enabled sustainable supply } \\
\text { chains in the 21st century: A review and } \\
\text { a research agenda }\end{array}$ & $\begin{array}{l}\text { Science of the Total } \\
\text { Environment }\end{array}$ & 5589 & 2020 & 0 & 106 & [70] \\
\hline 23 & $\begin{array}{l}\text { A holonic framework for managing the } \\
\text { sustainable supply chain in emerging } \\
\text { economies with smart } \\
\text { connected metabolism }\end{array}$ & $\begin{array}{l}\text { Resources, } \\
\text { Conservation \& } \\
\text { Recycling }\end{array}$ & 7044 & 2019 & 8 & 105 & [71] \\
\hline 24 & $\begin{array}{l}\text { When stakeholder pressure drives the } \\
\text { circular economy Measuring the } \\
\text { mediating role ofinnovation capabilities }\end{array}$ & Management Decision & 1963 & 2018 & 23 & 105 & [75] \\
\hline 25 & $\begin{array}{l}\text { Supplier relationship management for } \\
\text { circular economy Influence of external } \\
\text { pressures and top } \\
\text { management commitment }\end{array}$ & Management Decision & 1963 & 2018 & 22 & 104 & [66] \\
\hline 26 & $\begin{array}{l}\text { In support of open-loop supply chains: } \\
\text { Expanding the scope of environmental } \\
\text { sustainability in reverse supply chains }\end{array}$ & $\begin{array}{l}\text { Journal of Cleaner } \\
\text { Production }\end{array}$ & 6395 & 2019 & 7 & 103 & [65] \\
\hline 27 & $\begin{array}{l}\text { The Healthcare Sustainable Supply } \\
\text { Chain 4.0: The Circular Economy } \\
\text { Transition Conceptual Framework with } \\
\text { the Corporate Social } \\
\text { Responsibility Mirror }\end{array}$ & Sustainability & 2592 & 2019 & 10 & 103 & [63] \\
\hline 28 & $\begin{array}{l}\text { Renewable chemical feedstock supply } \\
\text { network design: The case of terpenes }\end{array}$ & $\begin{array}{l}\text { Journal of Cleaner } \\
\text { Production }\end{array}$ & 6395 & 2019 & 5 & 101 & [83] \\
\hline 29 & $\begin{array}{l}\text { Paving the way for the circular economy } \\
\text { and more sustainable supply chains: } \\
\text { Shedding light on formal and informal } \\
\text { governance instruments used to induce } \\
\text { green networks }\end{array}$ & $\begin{array}{l}\text { Management of } \\
\text { Environmental Quality: } \\
\text { An International } \\
\text { Journal }\end{array}$ & 0 & 2019 & 11 & 101 & [82] \\
\hline 30 & $\begin{array}{l}\text { Pricing and advertising strategies in } \\
\text { conceptual waste management planning }\end{array}$ & $\begin{array}{l}\text { Journal of Cleaner } \\
\text { Production }\end{array}$ & 6395 & 2019 & 4 & 100 & [67] \\
\hline 31 & $\begin{array}{l}\text { Analysis of network design for a circular } \\
\text { production system using multi-objective } \\
\text { mixed integerlinear } \\
\text { programming model }\end{array}$ & $\begin{array}{l}\text { Journal of } \\
\text { Manufacturing } \\
\text { Technology } \\
\text { Management }\end{array}$ & 2642 & 2019 & 7 & 100 & [89] \\
\hline 32 & $\begin{array}{l}\text { Contribution of upcycling surplus } \\
\text { hydrogen to design a sustainable supply } \\
\text { chain: The case study of Northern Spain }\end{array}$ & Applied Energy & 8426 & 2018 & 11 & 99 & [93] \\
\hline 33 & $\begin{array}{l}\text { Barriers to circular food supply chains } \\
\text { in China }\end{array}$ & $\begin{array}{c}\text { Supply Chain } \\
\text { Management: An } \\
\text { International Journal }\end{array}$ & 4296 & 2019 & 4 & 98 & [60] \\
\hline 34 & $\begin{array}{l}\text { The role of the focal company in } \\
\text { sustainable development goals: a } \\
\text { Brazilian food poultry supply chain } \\
\text { case study }\end{array}$ & $\begin{array}{l}\text { Journal of Cleaner } \\
\text { Production }\end{array}$ & 6395 & 2019 & 1 & 97 & [80] \\
\hline 35 & $\begin{array}{l}\text { Sustainable planning strategies in } \\
\text { supply chain systems: proposal and } \\
\text { applications with a real case study } \\
\text { in fashion }\end{array}$ & $\begin{array}{c}\text { Production } \\
\text { Planning \& Control }\end{array}$ & 3340 & 2019 & 2 & 95 & [77] \\
\hline 36 & $\begin{array}{l}\text { The value of advance payment financing } \\
\text { to carbon emission reduction and } \\
\text { production in a supply chain with game } \\
\text { theory analysis }\end{array}$ & $\begin{array}{l}\text { International Journal of } \\
\text { Production Research }\end{array}$ & 3199 & 2019 & 2 & 95 & [91] \\
\hline 37 & $\begin{array}{l}\text { Sustainable supply chain flexibility and } \\
\text { its relationship to circular } \\
\text { economy-target performance }\end{array}$ & $\begin{array}{l}\text { International Journal of } \\
\text { Production Research }\end{array}$ & 3199 & 2019 & 2 & 95 & [62] \\
\hline
\end{tabular}

\section{References}

1. World Health Organization. Coronavirus Disease (COVID-19). Coronavirus Disease (COVID-19) Pandemic. 2021. Available online: https: / / www.who.int/emergencies/diseases/novel-coronavirus-2019 (accessed on 22 September 2021).

2. Maliszewska, M.; Mattoo, A.; Mensbrgghe, D. The Potential Impact of COVID-19 on GDP and Trade A Preliminary Assessment; Policy Research Working Papers; World Bank Group: Washington, DC, USA, 2020; Volume 9211, pp. 1-24.

3. Everingham, P.; Chassagne, N. Post COVID-19 ecological and social reset: Moving away from capitalist growth models towards tourism as Buen Vivir. Tour. Geogr. 2020, 22, 555-566. [CrossRef] 
4. McGlade, J.; Palahí, M.; Pantsar, M.; Costanza, R.; Kubiszewski, I.; Potočnik, J.; Stuchtey, M.; Nasi, R.; Lovins, H.; Giovannini, E.; et al. Investing in Nature to Transform the Post COVID-19 Economy: A 10-point Action Plan to create a circular bioeconomy devoted to sustainable wellbeing. Solut. J. 2020, 11. Available online: https://discovery.ucl.ac.uk/id/eprint/10108755/ (accessed on 16 November 2021).

5. Kim, R.Y. The Impact of COVID-19 on Consumers: Preparing for Digital Sales. IEEE Eng. Manag. Rev. 2020, $48,212-218$. [CrossRef]

6. Lopes, I.B.; Viana, M.M.; Alfinito, S. Redes alimentares alternativas em meio à COVID-19: Reflexões sob o aspecto da resiliência. Rev. Eletrôn. Gestão Soc. 2020, 14, 3526-3544. [CrossRef]

7. Lovelace, R.; Talbot, J.; Morgan, M.; Lucas-Smith, M. Methods to Prioritise Pop-up Active Transport Infrastructure. Transp. Find. 2020. [CrossRef]

8. Agrawal, S.; Jamwal, A.; Gupta, S. Effect of COVID-19 on the Indian Economy and Supply Chain. Preprints 2020, 1-15. [CrossRef]

9. Jabbour, C.; Jabbour, A. COVID-19 is Contaminating the Sustainability of Supply Chains. Supply Chain Manag. Rev. 2020, 1-2. Available online: https://www.scmr.com/article/covid_19_is_contaminating_the_sustainability_of_supply_chains (accessed on 16 November 2021).

10. Wuyts, W.; Marin, J.; Brusselaers, J.; Vrancken, K. Circular economy as a COVID-19 cure? Resour. Conserv. Recycl. 2020, $162,105016$. [CrossRef]

11. Kahlert, S.; Bening, C.R. Plastics recycling after the global pandemic: Resurgence or regression? Resour. Conserv. Recycl. 2020, 160, 104948. [CrossRef]

12. Hazen, B.T.; Russo, I.; Confente, I.; Pellathy, D. Supply chain management for circular economy: Conceptual framework and research agenda. Int. J. Logist. Manag. 2020, 32, 510-537. [CrossRef]

13. Dey, B.K.; Bhuniya, S.; Sarkar, B. Involvement of controllable lead time and variable demand for a smart manufacturing system under a supply chain management. Expert Syst. Appl. 2021, 184, 115464. [CrossRef]

14. Bhuniya, S.; Pareek, S.; Sarkar, B. A supply chain model with service level constraints and strategies under uncertainty. Alex. Eng. J. 2021, 60, 6035-6052. [CrossRef]

15. Martins, C.; Pato, M. Supply chain sustainability: A tertiary literature review. J. Clean. Prod. 2019, 225, 995-1016. [CrossRef]

16. Merli, R.; Preziosi, M.; Acampora, A. How do scholars approach the circular economy? A systematic literature review. J. Clean. Prod. 2018, 178, 703-722. [CrossRef]

17. Stahel, W.R. The circular economy. Nature 2016, 531, 435-438. [CrossRef]

18. Su, B.; Heshmati, A.; Geng, Y.; Yu, X. A review of the circular economy in China: Moving from rhetoric to implementation. J. Clean. Prod. 2013, 42, 215-227. [CrossRef]

19. Kuo, T.-C.; Chiu, M.-C.; Chung, W.-H.; Yang, T.-I. The circular economy of LCD panel shipping in a packaging logistics system. Resour. Conserv. Recycl. 2019, 149, 435-444. [CrossRef]

20. Castiglione, C.; Alfieri, A. Supply chain and eco-industrial park concurrent design. IFAC-PapersOnLine 2019, 52, 1313-1318. [CrossRef]

21. Bressanelli, G.; Perona, M.; Saccani, N. Challenges in supply chain redesign for the Circular Economy: A literature review and a multiple case study. Int. J. Prod. Res. 2018, 57, 7395-7422. [CrossRef]

22. Raza, S.A. A systematic literature review of closed-loop supply chains. Benchmarking Int. J. 2020, 27, 1765-1798. [CrossRef]

23. Potting, J.; Hekkert, M.; Worrell, E.; Hanemaaijer, A. Circular Economy: Measuring Innovation in the Product Chain; PBL Netherlands Environmental Assessment Agency: The Hague, The Netherlands, 2017.

24. Boesen, S.; Bey, N.; Niero, M. Environmental sustainability of liquid food packaging: Is there a gap between Danish consumers' perception and learnings from life cycle assessment? J. Clean. Prod. 2018, 210, 1193-1206. [CrossRef]

25. Guarnieri, P.; Streit, J.A.C.; Batista, L.C. Reverse logistics and the sectoral agreement of packaging industry in Brazil towards a transition to circular economy. Resour. Conserv. Recycl. 2019, 153, 104541. [CrossRef]

26. Batista, L.; Gong, Y.; Pereira, S.; Jia, F.; Bittar, A. Circular supply chains in emerging economies-A comparative study of packaging recovery ecosystems in China and Brazil. Int. J. Prod. Res. 2018, 57, 7248-7268. [CrossRef]

27. EMF, Ellen Macarthur Foundation. Growth Within: A Circular Economy Vision for a Competitive Europe; Ellen Macarthur Foundation: London, UK, 2015.

28. Lopes de Sousa Jabbour, A.B.; Rojas Luiz, J.V.; Rojas Luiz, O.; Jabbour, C.J.C.; Ndubisi, N.O.; Caldeira de Oliveira, J.H.; Junior, F. H Circular economy business models and operations management. J. Clean. Prod. 2019, 235, 1525-1539. [CrossRef]

29. Genovese, A.; Acquaye, A.A.; Figueroa, A.; Koh, S.L. Sustainable supply chain management and the transition towards a circular economy: Evidence and some applications. Omega 2017, 66, 344-357. [CrossRef]

30. Pishchulov, G.V.; Richter, K.K.; Pakhomova, N.V.; Tsenzharik, M.K. A circular economy perspective on sustainable supply chain management: An updated survey. St Petersburg Univ. J. Econ. Stud. 2018, 34, 267-297. [CrossRef]

31. Carter, C.R.; Easton, P.L. Sustainable supply chain management: Evolution and future directions. Int. J. Phys. Distrib. Logist. Manag. 2011, 41, 46-62. [CrossRef]

32. Carter, C.R.; Rogers, D.S. A framework of sustainable supply chain management: Moving toward new theory. Int. J. Phys. Distrib. Logist. Manag. 2008, 38, 360-387. [CrossRef] 
33. Fritz, M. Sustainable supply chain management. In Responsible Consumption and Production. Encyclopedia of the UN Sustainable Development Goals; Leal, F.W., Azul, A., Brandli, L., Özuyar, P., Wall, T., Eds.; Springer: Berlin/Heidelberg, Germany, 2019; pp. $1-14$.

34. Mosteanu, N.R.; Faccia, A.; Ansari, A.; Shamout, M.D.; Capitanio, F. Sustainability integration in supply chain management through systematic literature review. Qual.-Access Success 2020, 21, 117-123.

35. Centobelli, P.; Cerchione, R.; Chiaroni, D.; Del Vecchio, P.; Urbinati, A. Designing business models in circular economy: A systematic literature review and research agenda. Bus. Strat. Environ. 2020, 29, 1734-1749. [CrossRef]

36. Webster, J.; Watson, R.T. Analyzing the past to prepare for the future: Writing a literature review Reproduced with permission of the copyright owner. Further reproduction prohibited without permission. MIS Q. 2002, 26, 13-23.

37. Tranfield, D.; Denyer, D.; Smart, P. Towards a Methodology for Developing Evidence-Informed Management Knowledge by Means of Systematic Review. Br. J. Manag. 2003, 14, 207-222. [CrossRef]

38. Cronin, P.; Ryan, F.; Coughlan, M. Undertaking a Literature Review: A step-by-step approach. Br. J. Nurs. 2008, 17, 38-443. [CrossRef] [PubMed]

39. Denyer, D.; Tranfield, D. Producing a Systematic Review. In The SAGE Handbook of Organizational Research Methods; Sage Publication: Thousand Oaks, CA, USA, 2009; pp. 671-689.

40. Souza, M.T.; Silva, M.D.; Carvalho, R. Integrative review: What is it? How to do it? Einstein 2010, 8, 102-106. [CrossRef] [PubMed]

41. Cooper, H. Synthesising Research: A Guide for Literature Reviews, 3rd ed.; Sage Publication: Thousand Oaks, CA, USA, 1998.

42. Pagani, R.N.; Kovaleski, J.; Resende, L.M. Methodi Ordinatio: A proposed methodology to select and rank relevant scientific papers encompassing the impact factor, number of citation, and year of publication. Scientometrics 2015, 105, 2109-2135. [CrossRef]

43. Chadegani, A.A.; Salehi, H.; Yunus, M.M.; Farhadi, H.; Fooladi, M.; Farhadi, M.; Ebrahim, N.A. A Comparison between Two Main Academic Literature Collections: Web of Science and Scopus Databases. Asian Soc. Sci. 2013, 9, 18-26. [CrossRef]

44. Harzing, A.W.; Alakangas, S. Google Scholar, Scopus and the Web of Science: A longitudinal and cross-disciplinary comparison. Scientometrics 2016, 106, 787-804. [CrossRef]

45. Pinto, M.M.A.; Kovaleski, J.L.; Yoshino, R.T. Uma análise da evolução da produção científica sobre Green Supply Chain Management. Espacios 2016, 37, 1-16.

46. Cappellesso, G.; Thomé, K.M. Technological innovation in food supply chains: Systematic literature review. Br. Food J. 2019, 121, 2413-2428. [CrossRef]

47. Silva, W.; Guarnieri, P.; Carvalho, J.; Farias, J.; Reis, S. Sustainable Supply Chain Management: Analyzing the Past to Determine a Research Agenda. Logistics 2019, 3, 14. [CrossRef]

48. de Carvalho, G.D.G.; Sokulski, C.C.; da Silva, W.V.; de Carvalho, H.G.; de Moura, R.V.; de Francisco, A.C.; da Veiga, C.P. Bibliometrics and systematic reviews: A comparison between the Proknow-C and the Methodi Ordinatio. J. Inf. 2020, 14, 101043. [CrossRef]

49. Cooper, D.; Schindler, P. Métodos de Pesquisa em Administração, 12th ed.; Bookman: Porto Alegre, Brazil, 2016.

50. Borgatti, S.; Everett, M.; Freeman, L. UCINET 6 for Windows: Software for Social Network Analysis; Analytic Technology: Harvard, MA, USA, 2002.

51. Souza, Q.; Quandt, C. Metodologia de Análises de Redes Sociais. In O Tempo das Redes; Perspectiva: São Paulo, Brasil, 2008; Volume 10, pp. 31-63.

52. Camargo, B.V.; Justo, A.M. IRAMUTEQ: Um software gratuito para análise de dados textuais. Temas em Psicol. 2013, 21, 513-518. [CrossRef]

53. EMF. Towards the Circular Economy: Accelerating the Scale-Up Across Global Supply Chains; Ellen Macarthur Foundation: London, UK, 2014.

54. European Comission. Closing the Loop—An EU Action Plan. for the Circular Economy; European Comission: Luxembourg, 2015.

55. Jia, F.; Yin, S.; Chen, L.; Chen, X. The circular economy in the textile and apparel industry: A systematic literature review. J. Clean. Prod. 2020, 259, 120728. [CrossRef]

56. Pontes, A.T.; Angelo, A.C.M. Utilização da avaliação do ciclo de vida no contexto da economia circular. Sist. Gestão. 2019, 14, 424-434. [CrossRef]

57. Silva, V.L.; Teixeira, T.; Francisco, A.C.; Picinin, C.T.; Kovaleski, J.L.; Pagani, R.N. Vantagens, barreiras e estratégias para economia circular: Uma abordagem teórica. Exacta 2019, 17, 238-255. [CrossRef]

58. Storopoli, J.; Ramos, H.; Quirino, G.; Rufín, C. Themes and Methods in Sustainability Research. Rev. Gestão Ambient. E Sustentab. 2019, 8, 410-430. [CrossRef]

59. Jabbour, C.J.C.; Sarkis, J.; Jabbour, A.B.L.D.S.; Renwick, D.W.S.; Singh, S.K.; Grebinevych, O.; Kruglianskas, I.; Filho, M.G. Who is in charge? A review and a research agenda on the 'human side' of the circular economy. J. Clean. Prod. 2019, 222, 793-801. [CrossRef]

60. Farooque, M.; Zhang, A.; Liu, Y. Barriers to circular food supply chains in China. Supply Chain Manag. Int. J. 2019, 24, 677-696. [CrossRef]

61. Zhang, A.; Zhong, R.Y.; Farooque, M.; Kang, K.; Venkatesh, V.G. Blockchain-based life cycle assessment: An implementation framework and system architecture. Resour. Conserv. Recycl. 2019, 152, 104512. [CrossRef]

62. Bai, C.; Sarkis, J.; Yin, F.; Dou, Y. Sustainable supply chain flexibility and its relationship to circular economy-target performance. Int. J. Prod. Res. 2019, 58, 5893-5910. [CrossRef] 
63. Daú, G.; Scavarda, A.; Scavarda, L.F.; Portugal, V.J.T. The Healthcare Sustainable Supply Chain 4.0: The Circular Economy Transition Conceptual Framework with the Corporate Social Responsibility Mirror. Sustainability 2019, 11, 3259. [CrossRef]

64. Nasir, M.H.A.; Genovese, A.; Acquaye, A.; Koh, S.; Yamoah, F. Comparing linear and circular supply chains: A case study from the construction industry. Int. J. Prod. Econ. 2017, 183, 443-457. [CrossRef]

65. Kalverkamp, M.; Young, S.B. In support of open-loop supply chains: Expanding the scope of environmental sustainability in reverse supply chains. J. Clean. Prod. 2019, 214, 573-582. [CrossRef]

66. Dubey, R.; Gunasekaran, A.; Childe, S.J.; Papadopoulos, T.; Helo, P. Supplier relationship management for circular economy. Manag. Decis. 2019, 57, 767-790. [CrossRef]

67. Šomplák, R.; Kůdela, J.; Smejkalová, V.; Nevrlý, V.; Pavlas, M.; Hrabec, D. Pricing and advertising strategies in conceptual waste management planning. J. Clean. Prod. 2019, 239, 118068. [CrossRef]

68. Winkler, H. Closed-loop production systems-A sustainable supply chain approach. CIRP J. Manuf. Sci. Technol. 2011, 4, 243-246. [CrossRef]

69. Karaman, A.S.; Kilic, M.; Uyar, A. Green logistics performance and sustainability reporting practices of the logistics sector: The moderating effect of corporate governance. J. Clean. Prod. 2020, 258, 120718. [CrossRef]

70. Jabbour, C.J.C.; Fiorini, P.D.C.; Ndubisi, N.O.; Queiroz, M.M.; Piato, L. Digitally-enabled sustainable supply chains in the 21st century: A review and a research agenda. Sci. Total. Environ. 2020, 725, 138177. [CrossRef]

71. Martín-Gómez, A.; Aguayo-González, F.; Luque, A. A holonic framework for managing the sustainable supply chain in emerging economies with smart connected metabolism. Resour. Conserv. Recycl. 2018, 141, 219-232. [CrossRef]

72. Nascimento, D.L.M.; Alencastro, V.; Quelhas, O.L.G.; Caiado, R.G.G.; Garza-Reyes, J.A.; Rocha-Lona, L.; Tortorella, G. Exploring Industry 4.0 technologies to enable circular economy practices in a manufacturing context: A business model proposa. J. Manuf. Technol. Manag. 2019, 30, 607-627. [CrossRef]

73. Yadav, G.; Luthra, S.; Jakhar, S.K.; Mangla, S.K.; Rai, D.P. A framework to overcome sustainable supply chain challenges through solution measures of industry 4.0 and circular economy: An automotive case. J. Clean. Prod. 2020, 254, 120112. [CrossRef]

74. Zeng, H.; Chen, X.; Xiao, X.; Zhou, Z. Institutional pressures, sustainable supply chain management, and circular economy capability: Empirical evidence from Chinese eco-industrial park firms. J. Clean. Prod. 2016, 155, 54-65. [CrossRef]

75. Jakhar, S.K.; Mangla, S.K.; Luthra, S.; Kusi-Sarpong, S. When stakeholder pressure drives the circular economy. Manag. Decis. 2019, 57, 904-920. [CrossRef]

76. De Jesus, A.; Mendonça, S. Lost in Transition? Drivers and Barriers in the Eco-innovation Road to the Circular Economy. Ecol. Econ. 2018, 145, 75-89. [CrossRef]

77. Fung, Y.-N.; Choi, T.-M.; Liu, R. Sustainable planning strategies in supply chain systems: Proposal and applications with a real case study in fashion. Prod. Plan. Control. 2019, 31, 883-902. [CrossRef]

78. Xiao, X.; Zeng, H. Sustainable supply chain management and circular economy capability: Based on the perspective of institutional pressure. Xitong Gongcheng Lilun Shijian/Syst. Eng. Theory Pract. 2017, 37, 1793-1804. [CrossRef]

79. Park, J.; Sarkis, J.; Wu, Z. Creating integrated business and environmental value within the context of China's circular economy and ecological modernization. J. Clean. Prod. 2010, 18, 1494-1501. [CrossRef]

80. Pohlmann, C.; Scavarda, A.J.; Alves, M.B.; Korzenowski, A.L. The role of the focal company in sustainable development goals: A Brazilian food poultry supply chain case study. J. Clean. Prod. 2019, 245, 118798. [CrossRef]

81. Sehnem, S.; Jabbour, C.J.C.; Pereira, S.C.F.; de Sousa Jabbour, A.B.L. Improving sustainable supply chains performance through operational excellence: Circular economy approach. Resour. Conserv. Recycl. 2019, 149, 236-248. [CrossRef]

82. De Oliveira, M.C.C.; Machado, M.C.; Jabbour, C.J.C.; Jabbour, A.B.L.D.S. Paving the way for the circular economy and more sustainable supply chains. Manag. Environ. Qual. Int. J. 2019, 30, 1095-1113. [CrossRef]

83. Tsolakis, N.; Bam, W.; Srai, J.S.; Kumar, M. Renewable chemical feedstock supply network design: The case of terpenes. J. Clean. Prod. 2019, 222, 802-822. [CrossRef]

84. Franco, M.A. Circular economy at the micro level: A dynamic view of incumbents' struggles and challenges in the textile industry. J. Clean. Prod. 2017, 168, 833-845. [CrossRef]

85. Hussain, M.; Malik, M. Organizational enablers for circular economy in the context of sustainable supply chain management. $J$. Clean. Prod. 2020, 256, 120375. [CrossRef]

86. Batista, L.; Bourlakis, M.; Smart, P.; Maull, R. In search of a circular supply chain archetype-A content-analysis-based literature review. Prod. Plan. Control. 2018, 29, 438-451. [CrossRef]

87. Farooque, M.; Zhang, A.; Thürer, M.; Qu, T.; Huisingh, D. Circular supply chain management: A definition and structured literature review. J. Clean. Prod. 2019, 228, 882-900. [CrossRef]

88. Masi, D.; Day, S.; Godsell, J. Supply Chain Configurations in the Circular Economy: A Systematic Literature Review. Sustainability 2017, 9, 1602. [CrossRef]

89. Vimal, K.; Rajak, S.; Kandasamy, J. Analysis of network design for a circular production system using multi-objective mixed integer linear programming model. J. Manuf. Technol. Manag. 2019, 30, 628-646. [CrossRef]

90. Hong, J.; Zhang, Y.; Ding, M. Sustainable supply chain management practices, supply chain dynamic capabilities, and enterprise performance. J. Clean. Prod. 2018, 172, 3508-3519. [CrossRef]

91. Qin, J.; Han, Y.; Wei, G.; Xia, L. The value of advance payment financing to carbon emission reduction and production in a supply chain with game theory analysis. Int. J. Prod. Res. 2019, 58, 200-219. [CrossRef] 
92. Gupta, S.; Haq, A.; Ali, I.; Sarkar, B. Significance of multi-objective optimization in logistics problem for multi-product supply chain network under the intuitionistic fuzzy environment. Complex. Intell. Syst. 2021, 7, 2119-2139. [CrossRef]

93. Yáñez, M.; Ortiz, A.; Brunaud, B.; Grossmann, I.E.; Ortiz, I. Contribution of upcycling surplus hydrogen to design a sustainable supply chain: The case study of Northern Spain. Appl. Energy 2018, 231, 777-787. [CrossRef] 